\title{
TOTOBUANG
}

Volume $9 \quad$ Nomor 2, Desember 2021

Halaman 239-255

\section{KLASIFIKASI LEKSIKOSTATISTIK BAHASA BANGGOI DAN BAHASA HOTI DI KABUPATEN SERAM BAGIAN TIMUR \\ (Lexicostatistic Classification Of Banggai And Hoti Language In East Seram District)}

\author{
Erniati \\ Kantor Bahasa Provinsi Maluku \\ Kompleks LPMP Maluku, Jalan Tihu, Wailela, Rumah Tiga, Ambon, 97234 \\ Pos-el: erniatikemdikbud@gmail.com
}

Diterima: 1 Februari 2021; Direvisi: 16 September 2021; Disetujui: 5 Oktober 2021

doi: https://doi.org/10.26499/ttbng.v9i1.333

\begin{abstract}
This study is a lexicostatistical study that aims to classify words that are related statistically to classify similarities. This research is focused on Banggoi and Hoti languages spoken by the people in West Bula District, East Seram Regency, Maluku Province. The aim is to determine the kinship classification of Banggoi and Hoti languages and determine the time of separation between the two languages. The method used is quantitative and qualitative methods with data collection techniques using direct observation, listening, note-taking, and recording methods. The results showed that Banggoi language and Hoti language have kinship with percentage of $31.5 \%$. Based on this percentage, the two languages are at the stok/family kinship level. The existence of this kinship is influenced by geographical proximity, while the time of separation of the two languages is estimated at 1,170 years ago.
\end{abstract}

Keywords: lexicostatistics, kinship, Banggoi language, Hoti language

Abstrak
Kajian ini merupakan kajian leksikostatistik yang bertujuan mengelompokkan kata-kata yang berkerabat dengan mengelompokkan persamaan secara statistik. Peneltian ini difokuskan pada bahasa Banggoi dan bahasa Hoti yang ditutukan oleh masyarakat yang ada di Kecamatan Bula Barat, Kabupaten Seram Bagian Timur, Provinsi Maluku. Tujuan kajian adalah untuk mengetahui klasifikasi kekerabatan bahasa Banggoi dan bahasa Hoti dan menentukan waktu pisah dari kedua bahasa tersebut. Penelitian ini menggunakan metode kuantitatif dan kualitatif dengan teknik pengambilan data dilakukan dengan menggunakan teknik observasi langsung, simak, catat, dan perekaman. Hasil penelitian menunjukkan bahwa antara bahasa Banggoi dan bahasa Hoti memilki kekerabatan dengan persentase 31,5\%. Berdasarkan persentase tersebut maka kedua bahasa tersebut berada pada tingkat kekerabatan stok/rumpun. Adanya kekerabatan bahasa Banggoi dan bahasa Hoti karena dipengaruhi oleh letak geografi yang berdekatan dan waktu pisah kedua bahasa tersebut diperkirakan pada 1.170 tahun yang lalu.

Kata-Kata kunci: leksikostatistik, kekerabatan, bahasa Banggoi, bahasa Hoti

\section{PENDAHULUAN}

Bahasa merupakan ciri identitas bangsa, melalui bahasa manusia dapat mengidentifikasi kelompoknya, mengenal perilaku dan mengenal kepribadian masyarakat penuturnya. Bahasa menjadi jembatan komunikasi antarmanusia untuk mengungkapkan segala ide dan pikiran manusia. Bahasa menjadi media yang dibutuhkan oleh setiap manusia untuk menghubungkannya dengan orang lain. Selain sebagai media komunikasi menurut Kridalaksana (2010, hlm. 21) bahasa merupakan sistem lambang bunyi yang arbitrer yang digunakan oleh para anggota sosial untuk bekerja sama, berkomunikasi, dan mengidentifikasi diri.

Bangsa Indonesia merupakan salah satu negara di dunia yang memiliki banyak suku bangsa atau etnis yang tersebar di 
tanah air. Suku atau etnis tersebut mendiami kepulauan Indonesia dari wilayah ujung Pulau Sumatra yakni Sabang hingga ke wilayah paling timur Indonesia yakni Merauke. Tiap etnis atau suku tersebut mempunyai bahasa masingmasing yang digunakan sebagai alat untuk berkomunikasi antarsesama, baik sesama suku atau etnis maupun antaretnis. Sebagai salah satu unsur kebudayaan, bahasa memiliki peran yang sangat penting sebagai sarana setiap manusia untuk menyampaikan maksud dan pokok pikirannya serta menjadi media mengekspresikan dirinya dalam berinteraksi dalam lingkup kemsyarakatan dan pergaulan. Bahasa menjadi tolak ukur manusia dalam berbagai sendi kehidupan manusia. Oleh karena itu, bahasa senantiasa dan seyogianya tetap harus dibina, dikembangkan, dilestarikan agar bahasa selalu mengikuti perkembangan pada setiap era atau zaman kehidupan ini.

Senada yang diungkapkan Theodora Bynon dalam (Erniati, 2020, hlm. 61), bahwa bahasa adalah sistem tanda yang mengungkapkan gagasan. Keberadaan bahasa dapat menjalin interaksi dalam masyarakat walaupun terdiri atas kelompok-kelompok etnis yang berbeda, Berkembang atau tidaknya suatu bahasa sangat ditentukan oleh pemilik bahasa itu sendiri atau penuturnya. Sebuah bahasa dinyatakan berkembang atau tidaknya bergantung pada masyarakat penuturnya. Perilaku masyarakat pada penggunaan bahasanya yang menentukan kondisi atau status sebuah bahasa. Perilaku kebahasaan masyarakat terhadap bahasanya akan berkembang seiring dengan perkembangan keheterogenan masyarakat. Semakin besar pemakaian sebuah bahasa akan semakin besar pula peluang terjadinya perubahan atau pergeseran bahasa tersebut.

Perkembangan penggunaan bahasa daerah tersebut perlu ditangani secara serius oleh berbagai kalangan. Mengingat jumlah bahasa daerah yang ada di
Indonesia sangat banyak dan beragam. Dengan jumlah penutur yang kecil sangat memungkinkan terjadi pergeseran penggunaannya. Data Summer International Linguistik (2006, hlm. 145) menunjukkan bahwa jumlah bahasa di Indonesia sebanyak 741 bahasa. Identifikasi bahasa daerah yang dipublikasikan tim pemetaan, Badan Pengembangan dan Pembinaan Bahasa, Kementerian Pendidikan dan Kebudayaan (Tim Pemetaan Bahasa, 2019) sebanyak 718 bahasa daerah dan penyumbang terbesar jumlah bahasa di Indonesia adalah dari Kepulauan Papua, Nusa Tenggara Timur dan Maluku. Jumlah bahasa daerah yang teridentifikasi di Maluku sebanyak 61 bahasa. Jika dibandingkan dengan jumlah bahasa daerah di luar Kepulauan Maluku misalnya di Pulau Sulawesi, Pulau Jawa, Kalimantan dan Sumatera. Jumlah ini sangatlah besar mengingat jumlah penduduk di Kepulauan Maluku hanya berkisar kurang lebih dua juta orang dan dapat dipastikan bahwa jumlah penuturnya sangat kecil. Namun begitu, upaya pelindungan terhadap bahasa tersebut tentu saja tidak boleh diabaikan. Bahasa-bahasa daerah di Maluku ini harus tetap dilakukana pembinaan, pengembangan dan pelestarian sama seperti bahasa daerah yang memilki jumlah penutur yang besar.

Bahasa-bahasa daerah di Maluku

oleh Summer International Linguistik (2006, hlm. 145) menyebutkan bahwa hampir semua bahasa daerah di Maluku merupakan rumpun bahasa Austronesia. Hal senada juga diungkapkan oleh pakar linguistik yang banyak melakukan penelitian bahasa di Maluku, James $\mathrm{T}$. Collins (2018, hlm. 35). Berdasarkan hal tersebut, sebagai bahasa yang memilki rumpun yang sama kemungkinan peluang memililki kekerabatan antarbahasa tersebut sangat besar. Menurut Sudarno (1991, hlm. 112) dalam Nursirwan (2012, hlm. 2) mengatakan bahwa hampir semua bahasa di Indonesia memiliki kesamaan atau 
kemiripan bentuk dan makna antarsatu bahasa daerah dengan bahasa yang lain. Hal ini tentu berlaku juga untuk bahasabahasa yang ada di wilayah Maluku. Meskipun jumlah etnis di wilayah timur Indonesia sangat banyak dan beragam dan memiliki bahasa sendiri-sendiri tetapi masih memungkinkan berkerabata karena berada di rumpun yang sama, yaitu rumpun Austronesia.

Dari sejumlah 61 bahasa daerah yang teridentifikasi oleh tim pemetaan Kantor Bahasa Provinsi Maluku dan Badan Pengembangan dan Pembinaan Bahasa di Provinsi Maluku, sebelas di antaranya ada di Kabupaten Seram Bagian Timur, yaitu bahasa Balkewan, Bobat, Boing, Elnama, Hoti, Leinam, Salas, Seram, Banggoi, Solan, dan Kesui. Sebagaimana telah disebutkan sebelumnya bahwa bahasa-bahasa di Maluku merupakan bahasa dengan rumpun Austronesia, begitu pun dengan bahasa yang ada di Kabupaten Seram Bagian Timur tersebut. Kesebelas bahasa daerah itu merupakan rumpun Austronesia, termasuk bahasa Hoti dan bahasa Banggoi. Bahasa Hoti dan bahasa Banggoi merupakan dua bahasa yag dituturkan oleh masyarakat Seram Timur bagian Selatan. Secara Geografis kedua bahasa ini terletak di wilayah yang berdekatan dengan wilayah kecamatan yang sama. Oleh karena itu sangat memungkinkan ada kekerabatan yang terjadi antara kedua bahasa tersebut.

Bahasa Banggoi dituturkan oleh masyarakat Desa Banggoi, Desa Banggoi Pancoran, dan Desa Dreamland Hills Kecamatan Bula Barat, Kabupaten Seram Bagian Timur, Provinsi Maluku. Menurut pengakuan penduduk, wilayah tutur bahasa Banggoi berbatasan dengan wilayah tutur bahasa Hoti di sebelah timur, merupakan rumpun Austronesia (Summer International Linguistik, 2006, hlm. 14).

Bahasa Hoti dituturkan oleh masyarakat di Desa Hote, Kecamatan Bula
Barat, Kabupaten Seram Bagian Timur, Provinsi Maluku. Menurut pengakuan penduduk di sebelah barat wilayah tutur bahasa Hoti berbatasan dengan wilayah tutur Banggoi. Berdasarkan hasil perhitungan dialektometri, isolek Hoti merupakan sebuah karena persentase perbedaannya dengan bahasa lain di Maluku berkisar 81\%--100\%, misalnya Seram dan Kaham (Tim Pemetaan Bahasa, 2017, hlm. 211).

Wilayah pakai yang berdekatan itu memungkinkan kedua bahasa itu telah terjadi kontak. Kontak antara kedua atau lebih bahasa itu secara mendalam dalam waktu yang lama berimplikasi pada saling memengaruhi sehingga unsur-unsur kebahasaan antara bahasa bahasa-bahasa yang memiliki kondisi geografis yang saling berdekatan (Fatinah, 2017). Kontak antara kedua atau lebih bahasa itu secara mendalam dan dalam waktu yang lama berimplikasi pada saling memengaruhi sehingga unsur-unsur kebahasaan antara bahasa bahasa-bahasa yang memilki kondisi geografis yang saling berdekatan (Fatinah, 2017). Begitu juga dengan bahasa Hoti dengan bahasa Banggoi. Kedua bahasa ini berasal dari rumpun bahasa yang sama sehingga antara kedua bahasa itu saling memperkaya sistem dan struktur bahasa-bahasa turunannya. Unsurunsur kebahasaan kedua bahasa itu perlu ditelaah secara mendetail, baik secara sinkronis maupun secara diakronis. Penelitian kebahasaan yang terkait bahasa Banggoi dan bahasa Hoti baik secara sinkronis maupun secara diakronis belum banyak dilakukan.

Selanjutnya, jika dua bahasa atau lebih berasal dari proto yang sama sangat memungkinkan memiliki kekerabatan karena memiliki wujud kesamaan korespondensi/kekerabatan baik pada tingkat fonologi maupun leksikal. Dengan melihat kesamaan antara kedua atau lebih bahasa tersebut maka akan diketahui kekerabatannya (Yohanis Sanjoko, 2013). 
Hubungan kekerabatan ketiga bahasa tersebut dapat dilihat dari bentuk kosakata dan maknanya. Kosakata bahasa Banggoi ditemukan kemiripan dengan bahasa Hoti. Contoh kosakata anak dalam bahasa Banggoi disebut ananem [ananem] dan dalam bahasa Hoti disebut ananam [ananam]. Kemiripan kosakata tersebut merupakan suatu ciri bahwa antara bahasa Banggoi dan bahasa Hoti memiliki hubungan kekerabatan. Berdasarkan contoh kosakata sebagai data yang dipaparkan tersebut maka penelitian kali ini mencoba melakukan kajian dengan menganalisisi kosakata bahasa Banggoi dan bahasa Hoti tersebut. Penelitian ini berfokus pada identifikasi kekerabatan bahasa Banggoi dan bahasa Hoti melalui analisisi leksikostatistik dalam kajian linguistik historis komparatif.

Penggunaan bahasa Banggoi dan bahasa Hoti oleh penuturnya sudah mengalami pergeseran yang sangat jauh. Bahasa Banggoi tidak lagi menjadi media komunikasi pagi penutur atau masyarakat Banggoi. Bahasa yang digunakan oleh masyarakat tutur bahasa Banggoi pada saat sekarang ini sudah bergeser ke bahasa Melayu dialek Ambon. Penutur bahasa Banggoi hanya yang berumur 50 tahun ke atas dan itu tidak menyeluruh. Sebagian masyarakat Banggoi yang berumur seperti itu sudah tidak bisa berkomunikasi dengan bahasa Banggoi. Kondisi seperti ini tentu saja memprihatinkan bagi bahasa Banggoi.

Kondisi bahasa Hoti tidak berbeda dengan bahasa Banggoi, bahkan status bahasa Hoti sudah menuju punah. Pada saat sekarang ini bahasa Hoti hanya dituturkan oleh orang tua yang berumur 60 tahun ke atas dan hanya ada beberapa orang. Bahasa Hoti sama sekali tidak diwariskan lagi untuk generasi muda. Dominasi penggunaan bahasa Melayu dialek Ambon menekan bahasa daerah termasuk bahasa Hoti. Oleh karena itu, salah satu jalan untuk menyelamatkan bahasa tersebut dengan melakukan pelindungan melalui dokumentasi bahasa. Dokumentasi bahasa ini dilakukan dengan mendata kosakatanya dari penutur yang masih bisa dijadikan informan kemudian dari dokumntasi tersebut dilakukan kajiankajian selanjutnya termasuk kajian kekerabatan antarbahasa tak terkecuali bahasa Banggoi dan bahasa Hoti.

Penelitian tentang kekerabatan bahasa di Maluku merupakan penelitian yang sangat menarik. Begitu pun dengan penelitian kekerabatan bahasa daerah di Pulau Seram terutama Kabupaten Seram Bagian Timur. Mengingat jumlah bahasa daerahnya begitu banyak dan berasal dari rumpun bahasa yang sama, yaitu rumpun Austronesia. Penelitian kekerabatan bahasa di Pulau Seram telah dilakukan oleh pakar bahasa sebelumnya seperti penelitian yang dilakukan oleh James T. Collins yang dilakukan pada tahun 1986, kemudian dibukukan oleh Kantor Bahasa Provinsi Maluku, Kementerian Pendidikan dan Kebudayaan (Badan Bahasa, 2019). Hasil penelitiannya menunjukkan bahwa bahasabahasa di Seram Timur merupakan cabang Proto-East Central Maluku. Artinya bahasa di Seram Timur itu merupakan anggota subkelompok yang sama dengan bahasa Watubela dan kemungkinan bahasa Banda. Bahasa Banda yang dimaksudkan ini adalah bahasa Banda Purba, menurutnya pula, bahasa Banda Purba diperkirkan digunakan di Pulau-Pulau Seram dan Kepulauan Maluku Tenggara, termasuk gugus Banda, bahasa Banda Purba sekerabat dengan bahasa seram Timur dan juga bahasa Nunusaku.

Penelitian kekerabatan bahasa daerah di Provinsi Maluku juga telah dilakukan oleh Erniati dengan judul Kekerabatan Bahasa Ambalau dan Bahasa Buru (2020, hlm. 61-73). Hasil penelitian menunjukkan berdasarkan penghitungan leksikostatistik berdasarkan bahasa Ambalau dan bahasa Buru masih berkerabat sebagai rumpun/stok bahasa 
dengan presentase kekognatan sebesar 24,5 $\%$. Penelitian kekerabatan bahasa-bahasa di Maluku juga pernah dilakukan Johana Grace Simon (Simon, 2015). Fokus kajiannya adalah kekerabatan bahasa Alune dan Wemale dan hasilnya menunjukkan bahwa berdasarkan metode glotokronologi dan leksikosatistik menunjukkan bahwa bahasa Alune dan Wemale termasuk dalam tingkatan bahasa mikrofilum dan waktu pisahnya dalam abad 50-75 tahun.

Selain itu, penelitian ini juga mengacu pada penelitian-penelitian kekerabatan yang lain yang telah banyak dilakukan oleh para peneliti di Indonesia, di antaranya, penelitian kekerabatan bahasa Kulawi dan bahasa Kaili di Sulawesi Tengah (Fatinah, 2017), penelitian kekerabatan bahasa-bahasa di kawasan utara Kabupaten Jayapura (Yohanis Sanjoko, 2013), penelitian kekerabatan yang dilakukan oleh Susiati yang mengkaji tentang bahasa-bahasa di Sulawesi Tenggara (Susiati, 2020), penelitian kekerabata bahasa Hitu dan bahasa Luhu (Wahidah, 2017).

Berdasarkan data hubungan kekerabatan kedua bahasa tersebut maka yang menjadi permasalahan dalam kajian ini adalah bagaimana mengklasifikasi hubungan kekerabatan bahasa Banggoi dan bahasa Hoti di Pulau Seram jika dilihat melalui metode leksikostatistik, kajian linguistik bandingan historis. Penelitian ini akan mengkaji secara khusus kosakata apa saja yang berkerabat antara bahasa Banggoi dan bahasa Hoti, berapa persentase hubungan kekerabataanya, dan kapan waktu pisah ketiga bahasa tersebut. Penelitian ini bertujuan untuk mengetahui, mengidentifikasi, dan mendeskripsikan hubungan kekerabatan bahasa Banggoi dan bahasa Hoti melalui metode leksikostatistik dengan mengidentifikasi jumlah kosakata yang berkerabat (sama/mirip), mengetahui persentasi kekerabatannya, dan mengetahui waktu pisah kedua bahasa tersebut.

Selanjutnya, penelitian diharapkan dapat menjadi salah satu acuan pengetahuan masyarakat penutur ketiga bahasa tersebut tentang ilmu kekerabatan bahasa, menjadi sumbangan ilmu pengetahuan tentang perkembangan bahasa-bahasa daerah di Maluku, memberikan sumbangan terhadap perkembangan ilmu linguistik historis komparatif di wilayah timur Indonesia, serta menjadi acuan terhadap berbagai asumsi yang berkembang di masyarakat tentang perbedaan dan persamaan kedua bahasa tersebut dan yang tidak kalah penting tentunya menjadi salah satu kajian dokumentasi bahasa daerah agar terhindar dari ancaman kepunahan.

\section{LANDASAN TEORI}

Linguistik bandingan historis atau linguistik historis komparatif adalah suatu cabang dari ilmu bahasa yang mempersoalkan bahasa dalam bidang waktu serta perubahan-perubahan unsur bahasa yang terjadi dalam bidang waktu tersebut. Salah satu tujuan dan kepentingan linguistik historis komparatif adalah mengadakan pengelompokkan (subgrouping) bahasa-bahasa dalam satu rumpun bahasa. bahasa-bahasa dalam suatu rumpun bahasa yang sama belum tentu sama tingkat kekerabatannya atau sama tingkat kemiripannya satu sama lain (Keraf, 2010, hlm. 22). Selanjutnya, masih pendapat Keraf (Keraf, 2010, hlm. 34) mengatakan bahwa bahasa-bahasa kerabat yang berasal dari proto yang sama selalu akan memperlihatkan kesemaan-kesamaan (1) kesamaan sistem bunyi (fonetik) dan susunan bunyi (fonologis); (2) kesamaan morfologis, yaitu kesamaan dalam bentuk 
kata dan kesamaan dalam bentuk gramatikal, (3) kesamaan sintaksis, yaitu kesamaan relasinya antara kata-kata dalam sebuah kalimat.

Menurut pendapat Mahsun (2011, hlm. 17), bahwa kajian linguistik historis komparatif (LHK) itu berpijak pada upaya mencari kesamaan (secara historis) unsur-unsur kebahasaan yang terdapat di antara bahasa-bahasa/isolekisolek yang diperbandingkan. Selain itu menjelaskan pula bahwa LHK juga mempersoalkan bahasa dalam hal kekerabatan serta perubahan unsur bahasa yang terjadu dalam kurun waktu tertentu. Pada prinsipnya bahasa-bahasa yang dipakai untuk berkomunikasi antarpenuturnya memiliki hubungan antara satu dengan yang lain meskipun bahasabahasa itu berjauhan. Antilla dalam (Fatinah, 2017, hlm. 248--261) mengemukakan bahwa kajian perbandingan antara dua bahasa atau lebih yang bertujuan menemukan kekerabatan bahasa-bahasa bahasa-bahasa yang diperbandingkan, baik secara kuantitatif maupun secara kualitatif dapat dilakukan melalui kajian linguistik historis komparatif (LHK). Selain itu, menurutnya pula bahwa kajian LHK itu mengemban beberapa tugas utama kebahasaan, di antaranya menetapkan fakta dan tingkat kekerabatan antarbahasa yang berkaitan erat dengan pngelompokan bahasa-bahasa yang sekerabat. Selanjutnya bahasa-bahasa yang termasuk ke dalam kelompok bahasa yang sekerabat atau yang sama diasumsikan memiliki sejarah perkembangan yang sama. Selain itu, kajian LHK memiliki kewenangan mengkaji relasi historis kekerabatan di antara sekelompok bahasa tertentu (Mahsun, 2011, hlm. 35).

Berdasarkan beberapa pendapat yang telah dijelaskan sebelumnya maka kajian linguistik historis komparatif bertujuan menjelaskan adanya hubungan kekerabatan dan kesejarahan bahasabahasa di suatu kawasan tertentu. Hubungan kekerabatan itu diabstraksikan dalam bentuk istilah, di balik hubunganhubungan itu tersirat fakta-fakta kebahasaan yang dijadikan sebagai dasar penentuan dan pembuktian hubungan kekerabatan. Fakta-fakta kebahasaan itu menggambarkan proses kesejarahan berkaitan dengan perubahan dan penelusuran unsur (statis) dan struktur bahasa, Bayond dalam (Fatinah, 2017). Oleh karena itu disimpulkan bahwa kajian LHK bertujuan untuk menjelaskan adanya hubungan kekerabatan dan kesejarahan bahasa-bahasa di suatu kawasan tertentu. Hubungan kekerabatan itu diabstraksikan dalam bentuk silsilah. Di balik hubungan itu tersirat fakta-fakta kebahasaan yang dijadikan sebagai dasar penentuan dan pembuktian hubungan kekerabatan. Faktafakta kebahasaan itu menggambarkan proses kesejarahan bahasa-bahasa kerabat itu dalam perjalanan waktu. Proses kesejarahan berkaitan dengan perubahan dan penelusuran unsur (statis) dan struktur bahasa Bayond dalam (Fatinah, 2017, hlm. 246--261).

Prinsip-prinsip kerja kajian linguistik historis komparatif dijalaskan oleh Mahsun (2005) dalam (Wahidah, 2017, hlm. 27) yaitu (1) menekankan hubungan-hubungan antara bahasa-bahasa serumpun dengan mengadakan perbandingan mengenai unsur-unsur yang menunjukkan hubungan dengan tingkat kekerabatan antara bahasa-bahasa itu, (2) mengadakan rekonstruksi bahasa-bahasa yang ada dewasa ini kepada bahasa-bahasa yang dianggap lebih tua atau menemukan bahasa-bahasa proto yang menurunkan bahasa kontemporer, dan (3) mengadakan pengelompokan (sub-grouping) bahasa- 
bahasa yang termasuk dalam rumpun bahasa. Ada beberapa bahasa yang memperlihatkan keanggotaannya lebih dekat satu sama lain apabila dibandingkan dengan beberapa anggota lainnya.

\section{METODE PENELITIAN}

Lokasi pengambilan data penelitian ini adalah bahasa Banggoi yang dituturkan di Desa Banggoi. Desa Banggoi merupakan desa tua di antara tiga desa lain yang menggunakan bahasa Banggoi, yaitu Desa Banggoi Pancoran dan Desa Dreamland Hills. Data diperoleh dari tururan langsung masyarakat tutur bahasa Banggoi yang ada di Desa Banggoi, Kecamatan Bula Barat, Kabupaten Seram Bagian Timur dan penutur bahasa Hote yang bermukim di Desa Hote, Kecamatan Bula Barat, Kabupaten Seram Bagian Timur.jumlah informan penelian ini sebanyak tiga orang, satu informan utama dan yang lainnya informan pendamping. Informan yang terpilih disesuaikan dengan syarat informan yang dikemukakan oleh Mahsun (2011, hlm. 45), yaitu (1) setiap informan minimal berumur empat puluh tahun; (2) memilki organ bicara dan mental yang normal; (3) orang tua, istri, atau suami informan dan informan yang bersangkutan lahir dan dibesarkan di desa atau di daerah pemakaian bahasa yang diteliti serta jarang atau tidak pernah meninggalkan desanya dalam waktu yang lama; dan (4) memiliki kebanggaan terhadap bahasa daerahnya, dalam arti yang bersangkutan selalu berusaha menggunakan bahasa daerahnya dalam setiap kesempatan.

Data bahasa Banggoi dan bahasa Hoti diperoleh melalui teknik wawancara dan angket yang sudah disusun dengan menggunakan daftar tanyaan 200 kosakata dasar Swadesh berdasarkan kuesioner pemetaan bahasa daerah di Indonesia yang disusun oleh tim pemetaan Bahasa dari Badan Bahasa, Kemdikbudristek. Peneliti mewawancarai informan sambil mencatat dan merekam setiap tuturan informan kedua bahasa tersebut. Setelah data dikumpulkan, langkah selanjutnya dianalisis sesuai kebutuhan atau tujuan penelitian. Data penelitian ini dianalisis dengan cara kerja metode leksikostatistik. Menurut Blust dalam Fatinah ( 2017, hlm. 253) cara kerja leksikotatistik dalam hal ini metode komparatif yaitu suatu cara kerja yang mengadakan identifikasi dan kodifikasi kemiripan antara bahasa yang berkerabat. Cara kerja metode komparatif yang diterapkan dalam penelitian adalah bersifat kuantitatif. Metode kuantitatif dalam kajian leksikostatistik digunakan untuk memulai atau mencari atau mengawali kajian kekerabatan.

Proses analisis data yang digunakan oleh peneliti mengikuti langkah-langkah leksikostatistk yang dikemukakan Keraf (2010, hlm. 126-- 129) sebagai berikut.

1. Mengumpulkan kosakata dasar bahasabahasa kerabat.

2. Menetapkan pasangan-pasangan kosakata yang merupakan kognat.

Sebuah pasangan kata akan dinyatakan kognat bila memenuhi salah satu ketentuan, sebagai berikut:

(a)pasangan kata itu identik, yaitu pasangan kata yang semua fonemnya sama betul,

(b)pasangan kata itu memiliki korespondensi fonemis,

(c)pasangan kata itu mirip secara fonetis, dan

(d)pasangan itu ada perbedaan satu fonem.

3. Menghitung jumlah kognat bahasabahasa kerabat.

Untuk menghitung kata-kata kognat dari beberapa bahasa kerabat dilakukan dengan langkah sebagai berikut'
(a)Mengeluarkan glos yang tidak diperhitungkan. Glos yang tidak 
diperhitungkan adalah kata-kata kosong, yaitu glos yang tidak ada katanya, baik dalam salah satu bahasa atau dalam semua bahasa. Selain itu semua pinjaman baik dari bahasa kerabat dan bahasa nonkerabat juga tidak diperhitungkan.

(b)Mengisolasi morfem terikat. Data-data yang mengandung morfem terikat harus dipisahkan antara bentuk dasar dengan semua morfem terikat yang melekat. Dengan melakukan pengisolasian morfem terikat akan lebih mudah apakah suatu pasangan menunjukkan kesamaan atau tidak.

Selanjutnya untuk menganalisis kuantitatif dilakukan dengan menggunakan rumus leksikostatistik yang juga dikemukakan oleh (Keraf, 2010), sebagai berikut.

$$
\Sigma \mathrm{K} \times 100 \%=\mathrm{d}
$$$$
\Sigma \mathrm{KB}
$$

$\Sigma \mathrm{K} \quad$ : jumlah persamaan kata kognat

$\Sigma \mathrm{KB}$ : jumlah kata yang diperbandingkan

d : persentase kekerabatan

Crowly dalam (Yohaniis Sanjoko, 2013:41-- 54) mengemukakan bahwa perbedaan persentase kognat akan menunjukkan tingkatan yang berbeda pengelompokkan bahasa. Tingkatan yang berbeda dalam sub-grouping diberi nama berbeda pula. Tingkatan-tingkatan tersebut adalah sebagai berikut.

Tabel 1

Tabel Persentase Kosakata Dasar

\begin{tabular}{|l|c|}
\hline Status & Persentase Persamaan Kosakata Dasar \\
\hline Bahasa & $81-100$ \\
\hline Keluarga & $36-81$ \\
\hline Stok/Rumpun & $12-36$ \\
\hline Mikrofilum & $4-12$ \\
\hline Mesofilum & $1-4$ \\
\hline Makrofilum & $0-1$ \\
\hline
\end{tabular}

HASIL DAN PEMBAHASAN

Kosakata Dasar Swadesh Bahasa Banggoi dan Bahasa Hoti

Analisis data dimulai dengan menampilkan kosakata dasar Swadesh bahasa Banggoi dan bahasa Hote. Berdasarkan kosakata dasar tersebut akan ditemukan berapa jumlah kosakata dasar yang memiliki kemiripan atau kesamaan fonem atau leksikon. Berikut data 200 kosakata dasar Swadesh bahasa Banggoi dan

bahasa

Hoti.

Tabel 2

Kosakata Dasar Swadesh Bahasa Banggoi dan Bahasa Hoti

\begin{tabular}{|l|l|l|l|c|}
\hline Nomor & \multicolumn{1}{|c|}{ Glos } & \multicolumn{1}{|c|}{$\begin{array}{c}\text { Bahasa Banggoi } \\
(\mathbf{1})\end{array}$} & \multicolumn{1}{c|}{$\begin{array}{c}\text { Bahasa Hoti } \\
\text { (2) }\end{array}$} & 1:2 \\
\hline 1 & Abu & keslaham & abu & - \\
\hline 2 & Air & weilam & wayla & + \\
\hline
\end{tabular}




\begin{tabular}{|c|c|c|c|c|}
\hline 3 & Akar & tablem & akar & - \\
\hline 4 & Alir (me-) & erbey & alir & - \\
\hline 5 & Anak & ananem & ananam & + \\
\hline 6 & Angin & semeylam & aGin & - \\
\hline 7 & Anjing & inuanam & Ewan & - \\
\hline 8 & Apa & esa & apa & - \\
\hline 9 & Api & waham & $\mathrm{mOla}$ & - \\
\hline 10 & Apung (me) & ermirmir & embul & - \\
\hline 11 & Asap & wahOynam & asab & - \\
\hline 12 & Awan & away & awa\&n & + \\
\hline 13 & Ayah & yeye & bapa & - \\
\hline 14 & Bagaimana & etunbObe & bagama & - \\
\hline 15 & Baik & $\mathrm{hOlO}$ & baik & - \\
\hline 16 & Bakar & ethOkO & bakkar & - \\
\hline 17 & Balik & Oliser & pulaG & - \\
\hline 18 & Banyak & laitem & ba na? & - \\
\hline 19 & Baring & etlet & ishrahat & - \\
\hline 20 & Baru & hOlhOlam & hOlam & + \\
\hline 21 & Basah & bOrOk & basah & - \\
\hline 22 & Batu & hatem & hatu & + \\
\hline 23 & Beberapa & ininhil & beb|rapa & - \\
\hline 24 & Belah (me-) & etbOlO & bala: & + \\
\hline 25 & Benar & batul & betul & + \\
\hline 26 & Bengkak & bOsOn & baGka & - \\
\hline 27 & Benih & bibit & anakan & - \\
\hline 28 & Berat & helan & $\mathrm{b} \mid \mathrm{rat}$ & - \\
\hline 29 & Berenang & et inen & bernaG & - \\
\hline 30 & Beri & etiba & itba & + \\
\hline 31 & Berjalan & et $\mathrm{Ou}$ & jalan & - \\
\hline 32 & Besar & bOtOn & basar & - \\
\hline 33 & Bilamana & bOhtel & bahal & + \\
\hline 34 & Binatang & binataG & binataG & + \\
\hline 35 & Bintang & Ohem & bintaG & - \\
\hline 36 & Buah & aihOnam & buwah & - \\
\hline 37 & Bulan & umelam & bulaG & - \\
\hline 38 & Bulu & kafultem & bulu+ bulu+ & - \\
\hline 39 & Bunga & buGa & buGa & + \\
\hline 40 & Bunuh & et amat & bunuh & - \\
\hline 41 & Buru (ber) & etet inwanem & bu+ru & - \\
\hline
\end{tabular}


Totobuang, Vol. 9, No. 2, Desember 2021: 239-255

\begin{tabular}{|c|c|c|c|c|}
\hline 42 & Buruk & tahOlO & tarba\&i? & - \\
\hline 43 & Burung & menam & manu & + \\
\hline 44 & Busuk & haun & busu+ & - \\
\hline 45 & Cacing & IOlem & caciG & - \\
\hline 46 & Cium & mala & ciyum & - \\
\hline 47 & Cuci & ulwa & bacuci & - \\
\hline 48 & Daging & wantam & dagin & - \\
\hline 49 & Dan & tu & $\mathrm{da}$ & - \\
\hline 50 & Danau & balam & talaga: & - \\
\hline 51 & Darah & lahim & dalah & - \\
\hline 52 & Datang & et hOrO & dataG & - \\
\hline 53 & Daun & ai lanam & da+um & - \\
\hline 54 & Debu & keslaham & abu+ & - \\
\hline 55 & Dekat & latik & rapat & - \\
\hline 56 & Dengan & tu & $\mathrm{dEG}$ & - \\
\hline 57 & Dengar & yahuley & deGar & - \\
\hline 58 & Di dalam & dOy dalam & dOy dalam & + \\
\hline 59 & Di mana & ni ambe & di mana & - \\
\hline 60 & Di sini & ni enin & $\operatorname{nin}$ & + \\
\hline 61 & Di situ & dOy ajO? & situ & - \\
\hline 62 & Pada & $\mathrm{dOy}$ & para: & - \\
\hline 63 & Dingin & nidOl & didOl & + \\
\hline 64 & Diri (ber) & tOben & badiri & - \\
\hline 65 & Dorong & $\mathrm{su}$ & tola & - \\
\hline 66 & Dua & enlo & $d+a$ & - \\
\hline 67 & Duduk & etsO & etsa & + \\
\hline 68 & Ekor & itnam & ekor & - \\
\hline 69 & Empat & enhat & ampa & - \\
\hline 70 & Engkau & Ouw & kaw & + \\
\hline 71 & Gali & ete & gali & - \\
\hline 72 & Garam & musinam & masinam & + \\
\hline 73 & Garuk & et iyal & garu+ & - \\
\hline 74 & Gemuk,lemak & muhlen & gamu+ & - \\
\hline 75 & Gigi & nisir & gigi & - \\
\hline 76 & Gigit & Ot & at & + \\
\hline 77 & Gosok & mik & goso & - \\
\hline 78 & Gunung & bOulam & gunuG & - \\
\hline 79 & Hantam & paratan & pukul & - \\
\hline 80 & Hapus & miki & sikat & - \\
\hline
\end{tabular}




\begin{tabular}{|c|c|c|c|c|}
\hline 81 & Hati & atam & ate & + \\
\hline 82 & Hidung & nilum & niluG & + \\
\hline 83 & Hidup & hidup & hidup & + \\
\hline 84 & Hijau & hijO & hijjawa & + \\
\hline 85 & Hisap & musu & hisap & - \\
\hline 86 & Hitam & $1 \mathrm{ObOt}$ & itam & - \\
\hline 87 & Hitung & rek & rekEn & + \\
\hline 88 & Hujan & dOam & udam & + \\
\hline 89 & Ia & aiwanem & utaG & - \\
\hline 90 & Ibu & ya & iya & + \\
\hline 91 & Ikan & wOwOy & ian & - \\
\hline 92 & Ikat & enam & ikat & - \\
\hline 93 & Ini & $\mathrm{hO}$ & balE & - \\
\hline 94 & Istri & enin & inin & + \\
\hline 95 & Itu & mOhnanam & bini & - \\
\hline 96 & Jahit & ajO & itu+ & - \\
\hline 97 & Jalan (ber) & lObet & manjay & - \\
\hline 98 & Jantung & Ow & uw & + \\
\hline 99 & Jatuh & usam & jatuG & - \\
\hline 100 & Jauh & tinaha & jau+ & - \\
\hline 101 & Kabut & kOil & kuil & + \\
\hline 102 & Kaki & OmOynam & kabur & - \\
\hline 103 & kalau & kalau & kala+u & + \\
\hline 104 & Kami, kita & am & $\mathrm{am}$ & + \\
\hline 105 & Kamu & um & kum & + \\
\hline 106 & Kanan & taltalam & kanan & - \\
\hline 107 & Karena & karna & karena & + \\
\hline 108 & Kata (ber) & dindek & bicara & - \\
\hline 109 & Kecil & matikam & $\mathrm{k} \mid \mathrm{cil}$ & - \\
\hline 110 & Kelahi (ber) & nukali & bakalay & - \\
\hline 111 & Kepala & ulum & ulu & + \\
\hline 112 & Kering & mela & $\mathrm{k} \mid \mathrm{riG}$ & - \\
\hline 113 & Kiri & iblitam & kiri & - \\
\hline 114 & Kotor & kOtOr & kotor & + \\
\hline 115 & Kuku & itkilnam & kuku & - \\
\hline 116 & Kulit & intam & kuli & - \\
\hline 117 & Kuning & hatnam & kuniG & - \\
\hline 118 & Kutu & utu & utu & + \\
\hline
\end{tabular}


Totobuang, Vol. 9, No. 2, Desember 2021: 239-255

\begin{tabular}{|c|c|c|c|c|}
\hline 119 & Lain & lain & waileta & - \\
\hline 120 & Langit & laGit & lagi] & + \\
\hline 121 & Laut & lawu & lawu & + \\
\hline 122 & Lebar & lebar & lebar & + \\
\hline 123 & Leher & sOlOr & leher & - \\
\hline 124 & Lelaki & mOlnanam & manam & + \\
\hline 125 & Lempar & $\operatorname{tah}$ & lempar & - \\
\hline 126 & Licin & maklisuk & liciG & - \\
\hline 127 & Lidah & lelam & lilah & + \\
\hline 128 & Lihat & Ote & liya & - \\
\hline 129 & Lima & enlim & $\lim$ & + \\
\hline 130 & Ludah & hitO & ludah & - \\
\hline 131 & Lurus & lurus & lurus & + \\
\hline 132 & Lutut & tuler & lulu+ & - \\
\hline 133 & Main & male & maeG & - \\
\hline 134 & Makan & en & een & + \\
\hline 135 & Malam & nOni & malaG & - \\
\hline 136 & Mata & mater & mata & + \\
\hline 137 & Matahari & umelenam & umen & - \\
\hline 138 & Mati & mat & mate & + \\
\hline 140 & Merah & mahmahlam & $\mathrm{m} / \mathrm{ra}$ & - \\
\hline 141 & Mereka & ey & doG & - \\
\hline 142 & Minum & inwey & minuG & - \\
\hline 143 & Mulut & hOham & mulu+ & - \\
\hline 144 & Muntah & luwe & luwe & + \\
\hline 145 & Nama & nalam & nama & - \\
\hline 146 & Napas & nuhnawa & apas & - \\
\hline 147 & Nyanyi & ma $\sim$ na ni & ma $\sim \mathrm{Ga} \sim \mathrm{ni}$ & + \\
\hline 148 & Orang & mensi & menci & + \\
\hline 149 & Panas & lahaslam & panas & - \\
\hline 150 & Panjang & kOilam & panjaG & - \\
\hline 151 & Pasir & inenam & pasar & - \\
\hline 152 & Pegang & kObla & $\mathrm{pEgaG}$ & - \\
\hline 153 & Pendek & esun & pende & - \\
\hline 154 & Peras & bus & ramas & - \\
\hline 155 & Perempuan & muhnanam & muanam & + \\
\hline 156 & Perut & tuwam & porO & - \\
\hline 157 & Pikir & isna & piker & - \\
\hline
\end{tabular}




\begin{tabular}{|c|c|c|c|c|}
\hline 158 & Pohon & pOhOn & pOhon & + \\
\hline 159 & Potong & tal & tol & + \\
\hline 160 & Punggung & sisam & balakaG & - \\
\hline 161 & Pusar & tibur & pusa & - \\
\hline 162 & putih & butbutam & puti & - \\
\hline 163 & Rambut & ihluem & rambu+ & - \\
\hline 164 & Rumput & bOtutuem & rump+u & - \\
\hline 165 & Satu & ehne & esa & - \\
\hline 166 & Saya & ya & aku+ & - \\
\hline 167 & Sayap & ihlenan & sayap & - \\
\hline 168 & Sedikit & ihnil & sediki & - \\
\hline 169 & Sempit & $\mathrm{kOs}$ & tegepe & - \\
\hline 170 & Semua & etse & samuwa & - \\
\hline 171 & Siang & siata & siyata & + \\
\hline 172 & Siapa & sia & $\mathrm{sa}$ & + \\
\hline 173 & Suami & sOwnin & sOwnam & + \\
\hline 174 & Sungai & weilam & ilam & + \\
\hline 175 & Tahu & ulata & $\mathrm{ta}+\mathrm{u}$ & - \\
\hline 176 & Tahun & tahun & tawuG & + \\
\hline 177 & Tajam & $\mathrm{mOy}$ & layaG & - \\
\hline 178 & Takut & muta & taku+ & - \\
\hline 179 & Tali & iwelam & tali & - \\
\hline 180 & Tanah & keita & $\tan a$ & - \\
\hline 181 & Tangan & imam & $\mathrm{taGa}$ & - \\
\hline 182 & Tarik & huta & hela & - \\
\hline 183 & Tebal & wakley & tabal & - \\
\hline 184 & Telinga & tinam & taliGa & - \\
\hline 185 & Telur & tOlam & tolam & + \\
\hline 186 & Terbang & edih & lerbaG & - \\
\hline 187 & Tertawa & $\mathrm{mOh}$ & latawa & - \\
\hline 188 & Tetek & susur & susu & + \\
\hline 189 & Tidak & taul & seG & - \\
\hline 190 & Tidur & let & so $\sim \mathrm{GO}$ & - \\
\hline 191 & Tiga & entOl & ento & + \\
\hline 192 & Tikam (me) & luk & likaG & - \\
\hline 193 & Tipis & tipis & tipis & + \\
\hline 194 & Tiup & umak & liyap & - \\
\hline 95 & Tongkat & tuwa & loGka & - \\
\hline
\end{tabular}




\begin{tabular}{|l|l|l|l|c|}
\hline 196 & Tua & luilam & tuwa & - \\
\hline 197 & Tulang & tamOi & tulaG & - \\
\hline 198 & Tumpul & ulam & tumpul & - \\
\hline 199 & Ular & tuertOnam & tOnam & + \\
\hline 200 & Usus & tuwa & tu: & + \\
\hline \multicolumn{2}{|l}{ Jumlah kata berkognat }
\end{tabular}

Keterangan: $+=$ kata berkognat

- = kata tidak berkognat

\section{Persentase kekerabatan Bahasa Banggoi dan Bahasa Hoti}

Daftar 200 kosakata dasar Swadesh pada tabel 1 menunjukkan jumlah kosakata yang berkognat sama/mirip antara bahasa Banggoi dan bahasa Hoti sebanyak 63 kosakata. Beberapa kosakata tersebut berkognat sama secara fonem dan leksikon dan yang lainnya berkognat mirip atau berbenda fonem namun mengandung arti yang sama. Selanjutnya, setelah ditemukan jumlah kosakata berkognat antara bahasa Banggoi dan bahasa Hoti maka tahap berikutnya adalah mencari persentase kekognatan tersebut. Sebagaimana telah dijelaskan pada metode penelitian bahwa untuk menemukan persentase kekerabatan antarbahasa dengan menggunakan rumus leskikostatistik. Persentase kekerabatan bahasa Banggoi dan bahasa Hoti akan diuraikan sebagai berikut.

Jumlah kata kognat: 63 kosakata.

$$
\text { Rumus: } \frac{\Sigma \mathrm{K}}{\Sigma \mathrm{KB}} \times 100 \%=\mathrm{d}
$$

Diketahui $\Sigma$ K: 63

Jadi $\quad \mathrm{d} \quad \frac{\mathrm{63} \times 100 \%}{200}=31,5 \%$

d: $31,5 \%$

Berdasarkan hasil penghitungan persentase kekerabatan antarbahasa dengan menggunakan rumus leksikostatistik seperti di atas, maka dapat dijelaskan bahwa antara bahasa Banggoi dan Bahasa Hoti memiliki hubungan kekerabatan/ masih berkerabat dengan persentase hubungan kekerabatan sebanyak 31,5\%. Jika dihubungkan dengan persentase dasar penentuan hubungan kekerabatan antarbahasa yang dikemukakan oleh Keraf dalam (Ruriana, 2018:13--30) bahwa tingkat kekerabatan bahasa Banggoi dan bahasa Hoti termasuk dalam stok/rumpun 252 bahasa. Penentuan jenis kekerabatan ini didasarkan pada metode leksikostatistik, yaitu jika jika persentase berkisar (81$100 \%$ ) digolongkan ke dalam bahasa yang sama, keluarga (36-80\%), stok/rumpun (12-36\%), mikrofilum (4-12\%), mesofilum (1-4\%), atau makrofilum (kurang dari 1\%). Oleh karena itu, mengingat perbedaan persentase antara bahasa Banggoi dan bahasa Hoti menunjukkan angka 31,5\% maka dapat disimpulkan bahwa bahasa hubungan kekerabatan atara bahasa Banggoi dengan bahasa Hoti termasuk dalam kategori 
stok/rumpun bahasa. Untuk lebih jelasnya persentase kekerabatan bahasa Banggoi dan bahasa Hoti akan digambarkan melalui tabel berikut.

Tabel 3

Persentase Kekerabatan Bahasa Banggoi dan Bahasa Hoti

\begin{tabular}{|l|l|l|}
\hline & Lorang & \\
\hline Banggoi & $=$ & Hoti \\
\hline Hoti & 31,5 & $=$ \\
\hline
\end{tabular}

Persentase kekerabatan bahasa Banggoi dan bahasa Hoti yang digambarkan pada tabel di atas, selanjutnya akan dikonversikan melalui bagan silsilah kekerabatan antara bahasa
Banggoi dan bahasa Hoti dengan menggunakan angka-angka yang lebih sederhana. Angka presentase tersebut akan dikonversikan dalam bagan silsilah kekerabatan berikut.

Tabel 4

\section{Bagan Silsilah Kekerabatan Bahasa Banggoi dan Bahasa Hoti}

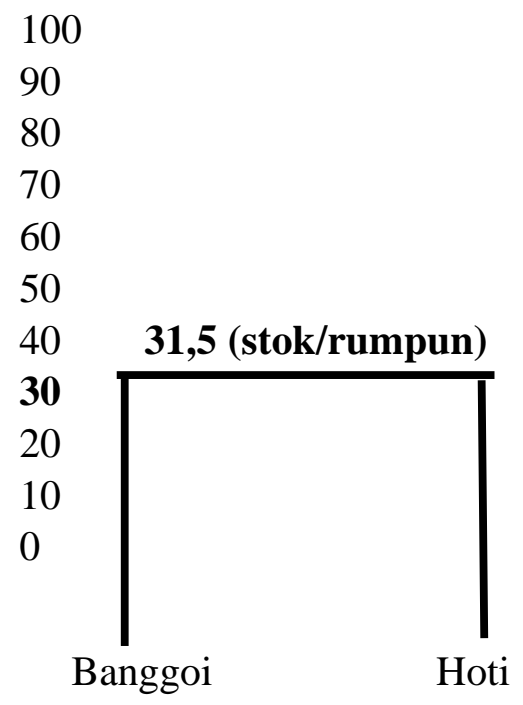

Tabel 3 tentang bagan silsilah kekerabatan bahasa Banggoi dan bahasa Hoti menunjukkan bahwa kedua bahasa itu benar-benar memiliki hubungan kekerabatan dengan persentase persamaan $31,5 \%$ dan berada pada tingkat stok/rumpun. Terjadinya hubungan kekerabatan kedua bahasa terseut dipengaruhi letak geografis yang berdekatan. Selain bagan silsilah kekerabatan, berikut ini akan digambarkan diagram pohon kekerabatan bahasa Banggoi dan bahasa Hoti untuk menunjukkan kekerabatan. 


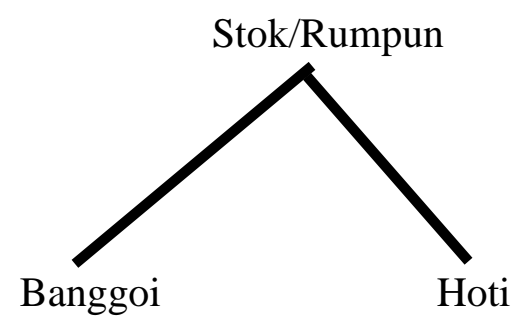

\section{Penentuan Waktu Pisah Bahasa Banggoi dan Bahasa Hoti}

Hasil persentase kekerabatan bahasa

Banggoi dan bahasa Hoti atau hasil kekekerabatan sudah diketahui maka analisis selanjutnya adalah dengan menghitung usia dan waktu pisah kedua bahasa tersebut. Untuk menghitung waktu pisah kedua bahasa atau lebih oleh para peneliti linguistik menggunakan teknik glatokronologi. Teknik ini dilakukan dengan cara mengonversikan ke dalam persentase kedua bahasa tersebut. Rumus yang digunakan untuk menghitung usia dan waktu pisah bahasa Banggoi dan bahasa Hoti akan diuraikan sebagai berikut.

$\mathrm{W}=\underline{\log .} \mathrm{C}$

$2 \log . r$

W : waktu perpisahan dalam ribuan

tahun yang lalu

$r$ : retensi, persentase konstan dalam

1000 tahun

C : persentase kerabat

log: logaritma

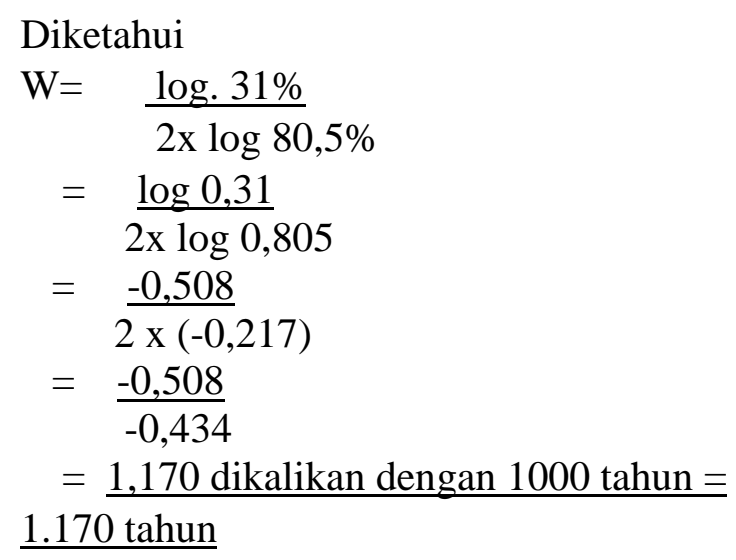

Jadi perhitungan waktu pisah bahasa Banggoi dan bahasa Hoti adalah 1.170 tahun yang lalu.

\section{PENUTUP}

Berdasarkan analisis klasifikasi bahasa Banggoi dan bahasa Hoti, maka dapat disimpulkan bahwa sesuai penghitungan leksikostatistik kedua bahasa tersebut memiliki kekerabatan sebagai stok/rumpun. Jumlah kosakata yang sama/mirip dari 200 kosakata dasar Swadesh yang diperbandingkan sebanyak 63 dengan persentase $31,5 \%$. Kekerabatan bahasa Banggoi dan bahasa Hoti ini dipengaruhi oleh letak geografi yang berdekatan. Kedua bahasa ini dituturkan pada satu wilayah kecamatan di Kabupaten Seram Bagian Timur. Sedangkan waktu pisah antara kedua bahasa tersebut diperkirakan pada 1,170 tahun yang lalu.

\section{DAFTAR PUSTAKA}

Badan Bahasa. (2019). Bahasa dan Peta Bahasa Indonesia. Jakarta: Badan Pengembangan dan Pmbinaan Bahasa

Erniati. (2020). Kekerabatan Bahasa Ambalau Dan Bahasa Buru Berdasarkan Daftar 200 Kosakata Dasar Swadesh: Kajian Leksikostatistik the Relationship of Ambalau and Buru Languages Based on List of 200 Basic Vocational Swadesh Vocational Schools : Study of Lecticostatistics. Gramatika, VIII, 60-73.

Fatinah, S. (2017). Kekerabatan Bahasa Kulawi Dan Bahasa Kaili Di 
Sulawesi Tengah. Kandai, 13(2), 249.

https://doi.org/10.26499/jk.v13i2.2 45

James, T. C. (2018). Penelitian Bahasa di Maluku (Issue 9). Kantor Bahasa Maluku. https://doi.org/10.1017/CBO97811 07415324.004

Keraf, G. A. (2010). lingustik Bandingan Historis.Jakarta: Gramedia Pustaka Utama.

Kridalaksana, H. (2010). Kelas Kata dalam Bahasa Indonesia. Jakarta: PT Gramedia Pustaka Utama.

Mahsun. (2011a). Dialektologi Diakronis. YogyakartaGadjah Mada University Pres.

Nursirwan, N. (2012). Klasifikasi Leksikostatistik Bahasa Melayu Langkat, Bahasa Melayu Deli, Dan Bahasa Dairi Pakpak. Fakultas Ilmu Budaya Universitas, 10.

Ruriana, P. (2018). Hubungan Kekerabatan Bahasa Jawa Dan Madura. Kandai,
14 , $15-30$. https://doi.org/10.26499/jk.v14i1.5 12

Sanjoko, Yohanis. (2013). Kekerabatan Bahasa Nafri, Sentani, dan Tabla: Kajian Leksikostatistik. Gramatika, 1, 41-54.

Simon, J. G. (2015). Kekerabatan Bahasa Alune dan Bahasa Wemale. Kajian Linguistik.https://doi.org/10.35796/ kaling.2.3.2015.8431

Summer International Linguistik. (2006). Bahasa-Bahasa di Indonesia. Jakarta: SIL Internasional Cabang Jakarta.

Susiati. (2020). Hubungan Kekerabata Bahasa Di Sulawesi Tenggara (Bahasa Wakatobi, Bahasa Cia-Cia, Bahasa Kioko, Bahasa Tolaki) OSF Preprints, 2-18.

Wahidah. (2017). Kekerabatan Bahasa Hitu dan Bahasa Luhu (Kajian Linguistik Historis Komparatif). Kantor Bahasa Maluku. 
